\title{
KONSEP CITRA KOTA PADA KAWASAN KOTA LAMA SEMARANG
}

\author{
Choirul Amin'1, Okky Wahyu Saputra², Ahmad Nurudin ${ }^{3}$ \\ ${ }^{1}$ Dosen Universitas 17 Agustus 1945 Semarang \\ 2,3Mahasiswa Universitas 17 Agustus 1945 Semarang \\ Alamat email penulis : pakminsubali@gmail.com
}

\begin{abstract}
ABSTRAK
Konsep Citra Kota merupakan salah satu teori yang diciptakan oleh Kevin Lynch dalam perancangan suatu kota. Teori ini bertujuan untuk memperkuat image atau citra dari sebuah kota itu sendiri dengan 5 teori elemen path, edge, district, node dan landmark.

Kawasan kota lama Semarang merupakan kawasan yang terdiri dari empat karakteristik yang unik yaitu Kampung Melayu, Kota Lama Belanda, Kauman dan Pecinan dan memiliki sejarah dalam perkembangan kota Semarang.

Penelitian ini bertujuan untuk menganalisa dan membuktikan bahwa konsep citra kota yang dikemukan oleh Kevin lynch dapat memperkuat image dari karakteristik ke empat kawasan tersebut sesuai dengan ciri masing masing dalam satu kesatuan kawasan kota lama Semarang

Peneliti melakukan analisa data yang didapatkan melalui peta kota lama Semarang saat ini kemudian dilakukan analisa menggunakan 5 teori citra kota milik Kevin Lynch yakni Path ( jalur ), Edge ( batas ), District ( kawasan ), Node ( simpul ) dan Landmark ( tetenger ).
\end{abstract}

Kata kunci: Konsep Citra Kota, Kawasan Kota Lama Semarang

\section{LATAR BELAKANG}

Kawasan kota lama Semarang terdiri dari 4 kawasan berbeda dalam satu area yakni : Kampung Melayu, Kota Lama Belanda, Kauman dan Pecinan, yang mempunyai kesinambungan sejarah dalam perkembangan kota Semarang dalam satu kawasan, akan tetapi mempunyai karakteristik yang cukup berbeda sesuai fungsinya pada saat ini

Keberadaan ke empat kawasan kota lama Semarang tersebut perlu dianalisa agar supaya keberadaanya semakin memperkuat karakteristik image area tersebut, baik setiap kawasan maupun sebagai satu kawasan kota lama Semarang sebagai suatu bagian perkembangan kota Semarang

Peneliti berusaha menganalisa dan membuktikan apakah dalam ke empat kawasan kota lama Semarang tersebut benar benar sesuai dengan pola atau konsep teori citra kota yang dikemukakan Kevin Lynch ( Path, Edge, District, Node dan Landmark ) dalam buku Markus Zahnd 1999, sebagai unsur unsur pembentuk citra kota dalam perancangan sebuah kota

\section{TEORI CITRA KOTA}

Elemen pembentuk citra kota menurut Kevin Lynch adalah:

\section{Paths}

Merupakan suatu jalur yang digunakan oleh pengamat untuk bergerak atau berpindah tempat. Menjadi elemen utama karena pengamat bergerak melaluinya pada saat mengamati kota dan disepanjang jalur tersebut elemen-elemen lingkungan lainnya tersusun dan dihubungkan. Path merupakan elemen yang paling penting dalam image kota yang menunjukkan rute-rute sirkulasi yang biasanya digunakan orang untuk melakukan pergerakan secara umum, yakni jalan, gang-gang utama, jalan transit, lintasan kereta api, saluran dan sebagainya. Path mempunyai identitas yang lebih baik kalau memiliki identitas yang besar (misalnya ke stasiun, tugu, alun-alun,dan lainlain), serta ada/ penampakan yang kuat (misalnya fasade, pohon, dan lain-lain), atau belokan yang jelas.

\section{Edges}

Merupakan batas, dapat berupa suatu desain, jalan, sungai, gunung. Edge memiliki identitas yang kuat karena tampak visualnya yang jelas. Edge merupakan penghalang walaupun kadang-kadang ada tempat untuk masuk yang merupakan pengakhiran dari sebuah district atau batasan sebuah district dengan yang lainnya. Edge memiliki identitas yang lebih baik jika kontinuitas tampak jelas 
batasnya. Demikian pula fungsi batasnya harus jelas : membagi atau menyatukan. Contoh : adanya jalan tol yang membatasi dua wilayah yaitu pelabuhan dan kawasan perdagangan.

\section{Districts}

Merupakan suatu bagian kota mempunyai karakter atau aktivitas khusus yang dapat dikenali oleh pengamatnya. District memiliki bentuk pola dan wujud yang khas begitu juga pada batas district sehingga orang tahu akhir atau awal kawasan tersebut. District memiliki ciri dan karakteristik kawasan yang berbeda dengan kawasan disekitarnya. District juga mempunyai identitas yang lebih baik jika batasnya dibentuk dengan jelas tampilannya dan dapat dilihat homogen, serta fungsi dan komposisinya jelas. Contoh: kawasan perdagangan, kawasan permukiman, daerah pinggiran kota, daera pusat kota.

\section{Nodes}

Merupakan simpul atau lingkaran daerah strategis di mana arah atau aktivitasnya saling bertemu dan dapat diubah ke arah atau aktivitas lain, misalnya persimpangan lalu lintas, stasiun, lapangan terbang, jembatan, kota secara keseluruhan dalam skala makro besar, pasar, taman, square, tempat suatu bentuk perputaran pergerakan, dan sebagainya. Node juga merupakan suatu tempat di mana orang mempunyai perasaan 'masuk' dan 'keluar' dalam tempat yang sama. Node mempunyai identitas yang lebih baik jika tempatnya memiliki bentuk yang jelas (karena lebih mudah diingat), serta tampilan berbeda dari lingkungannya (fungsi, bentuk). Contoh: persimpangan jalan

\section{Landmark}

Merupakan simbol yang menarik secara visual dengan sifat penempatan yang menarik perhatian. Biasanya landmark mempunyai bentuk yang unik serta terdapat perbedaan skala dalam lingkungannya. Beberapa landmark hanya mempunyai arti di daerah kecil dan hanya dapat dilihat di daerah itu, sedangkan landmark lain mempunyai arti untuk keseluruhan kota dan bisa di lihat dari manamana. Landmark adalah elemen penting dari bentuk kota karena membantu orang mengenali suatu daerah. Selain itu landmark bisa juga merupakan titik yang menjadi ciri dari suatu kawasan. Contoh: patung Lion di Singapura, menara Kudus, Kubah gereja Blenduk.

\section{METODE PENELITIAN}

Penelitian konsep citra kota pada kawasan kota lama Semarang ini mengunakan metode deskriptif dan pendekatan yang bersifat kualitatif. Peneliti berusaha menjabarkan dengan analisis fakta-fakta maupun temuan dalam penelitian ke dalam kata-kata yang sistematis, terstruktur, dan mudah dipahami. Penjabaran yang dimaksud adalah penyampaian hasil analisis dari kajian teori Kevin Lynch pada ke empat kawasan kota lama Semarang dikaitkan dengan variabel-variabel yang telah ditentukan secara urut dan sistematis. Variabel yang digunakan untuk menganalisis adalah Path ( jalur), Edge ( batas ), District ( kawasan ), Node ( simpul ) dan Landmark ( tetenger ) sesuai dengan teori citra kota pada perancangan urban design dalam buku Markus Zahnd tahun 1999

\section{DATA FISIK KOTA LAMA SEMARANG}

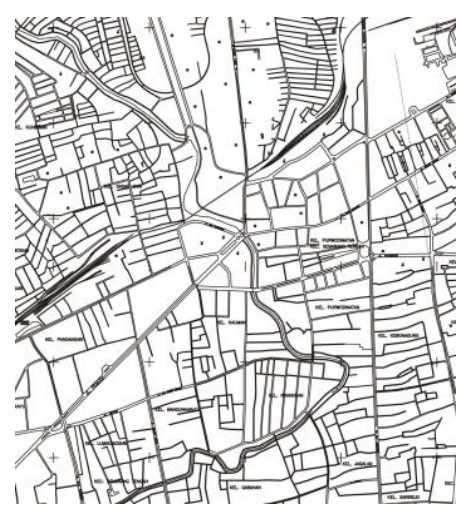

Peta Kota Lama Semarang

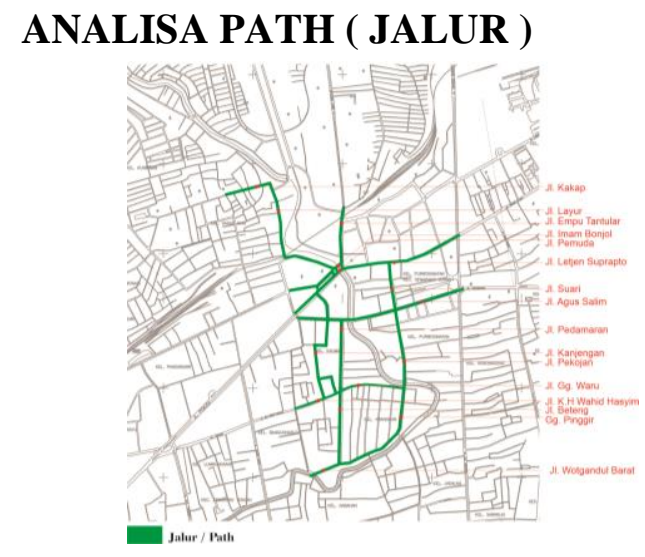

Analisa Jalur / Path Kota Lama Semarang

Jalur yang menghubungkan ke empat wilayah kota lama Semarang ( Kampung Melayu, Kota Lama Belanda, Pecinan dan Kauman ), mulai dari Jl. Kakap ( Kampung 
Melayu ) sampai dengan Jl. Wotgandul Barat ( Pecinan ), melewati antara lain $\mathrm{Jl}$ Layur, J1. Empu Tantular, J1. Imam Bonjol, J1. Pemuda, Jl. Letjen Suprapto, J1 Suari, J1. Agus Salim, Jl. Pedamaran, Jl. Kanjengan, Jl. Pekojan, Jl. Waru, Jl. Wahid Hasyim, Jl. Beteng, Gang Pinggir dan berakhir di Wotgandul Barat.

\section{ANALISA EDGE ( BATAS )}

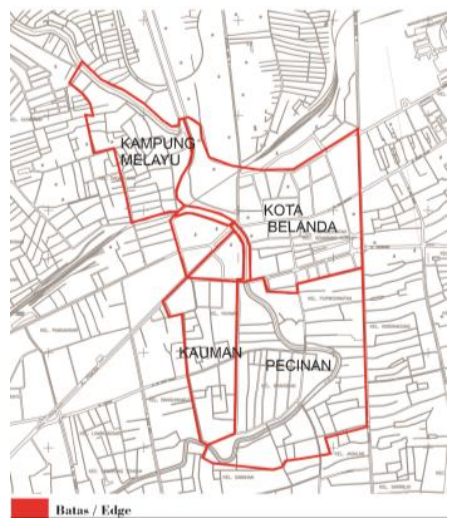

Analisa Batas / Egde Kota Lama Semarang

Kampung Melayu dan Kota Lama Belanda dibatasi oleh Kali Semarang, dengan pusat perbatasan melalui Jembatan Mberok. Kota Lama Belanda dan Pecinan dipisahkan oleh jalan Pattimura dan Jalan Ronggowarsito. Kampung Melayu dan Kauman dibatasi oleh ujung JAlan Pemuda ( Johar ), sedangkan Pecinan dan Kauman bersinggungan langsung dengan batas jalan Kauman.

\section{ANALISA DISTRICT ( KAWASAN )}

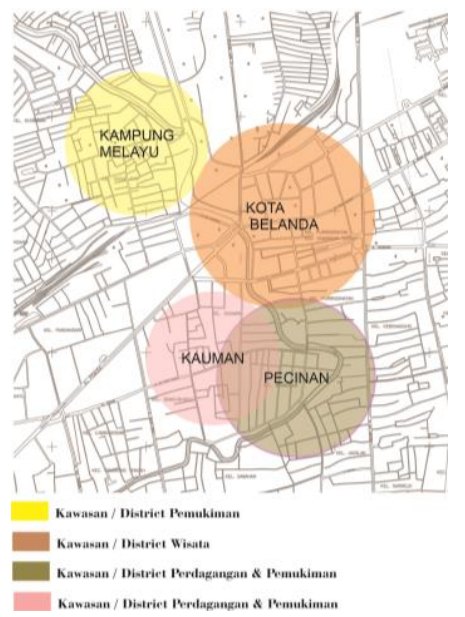

Analisa Kawasan / District Kota Lama Semarang
ANALISA NODE ( SIMPUL )

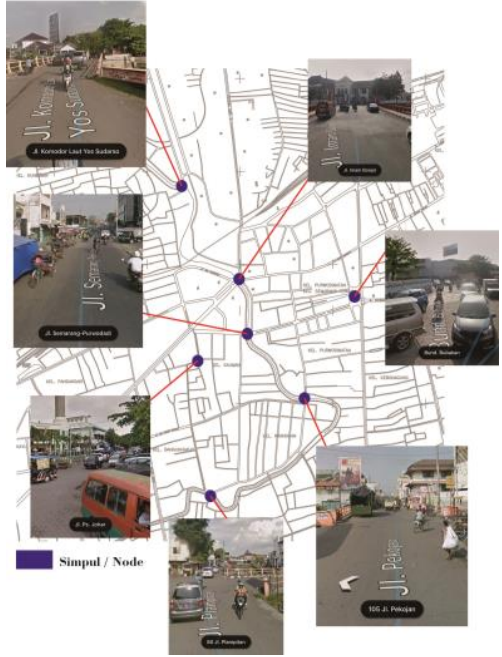

Analisa Simpul / Node Kota Lama Semarang

ANALISA LANDMARK ( TETENGER)

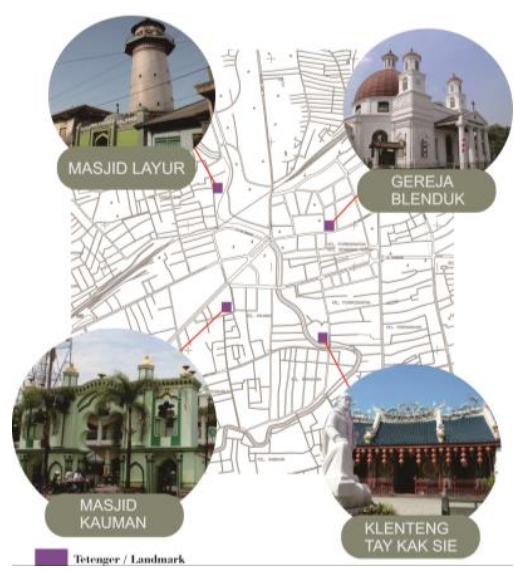

Analisa Tetenger / Landmark Kota Lama

Semarang

Landmark atau tetenger Kampung Melayu adalah Masjid Layur, tetenger Kota Lama Belanda adalah Gereja Blendhuk, tetenger Pecinan adalah Klenteng Tay Kak Sie, sedangkan tetenger Kauman adalah Masjid Kauman. Semua landmark yang ada di Kota Lama Semarang ternyata adalah bangunan ibadah berbagai agama, yang menunjukkan keragaman budaya yang masih terjalin hingga saat ini 
HASIL ANALISA

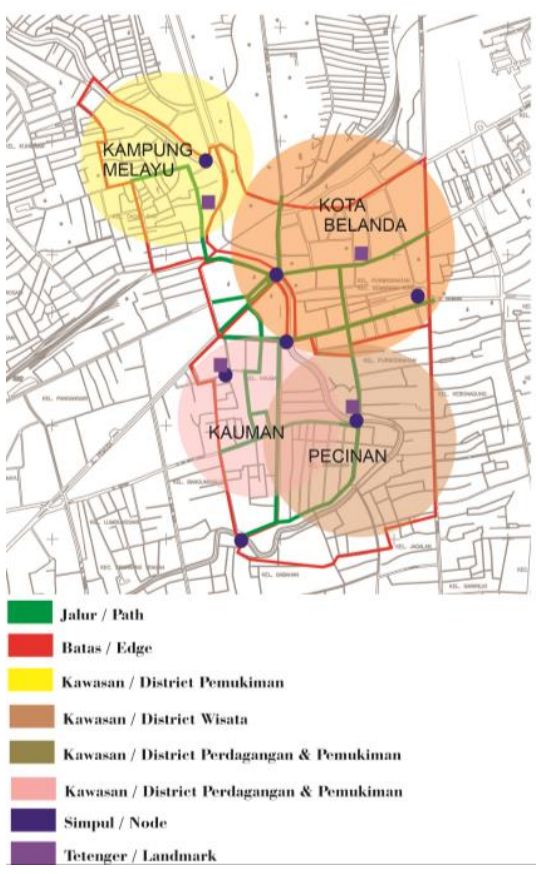

\section{KESIMPULAN}

- Path atau jalur jalur sirkulasi jalan penghubung utama pada ke empat kawasan kota lama Semarang, antara Kampung Melayu, Kota Lama Belanda, Kauman, dan Pecinan cukup jelas dan dirasa tidak membingungkan

- Batas wilayah atau Edge pada ke empat kawasan kota lama Semarang sangat jelas, sungai Kali Semarang sebagai pembatas bagian dalam dari ke empat wilayah tersebut dan juga batas administrasi jalan raya untuk bagian luar wilayah kota lama semarang

- District atau kawasan dengan karakteristik yang berbeda pada ke empat kawasan kota lama Semarang juga sangat terlihat jelas, Kampung melayu sebagai kawasan yang didominasi permukiman, Kota Lama Belanda sebagai kawasan pariwisata, Kauman sebagai kawasan perdagangan dengan ciri religi islam yang kental, dan Pecinan sebagai kawasan perdagangan yang mempunyai kekhasan budaya tionghoa

- Node atau simpul sebagai titik kumpul ataupun pembagi kawasan serta jalur keluar masuk area ke empat kawasan kota lama semarang juga sangat terlihat dengan titik node utama pada area Jembatan Mberok untuk simpul Kampung Melayu dan Kota Lama Belanda, serta perempatan / pertigaan pasar Johar sebagai node pembagi jalur kawasan Kauman dan pecinan

- Landmark atau tetenger bangunan yang mengingatkan kita pada suatu kawasan tertentu pada ke empat kawasan kota lama Semarang juga terlihat menonjol pada setiap kawasan yaitu : Gereja Blenduk sebagai tetenger Kota Lama Belanda, Masjid Layur sebagai tetenger Kampung Melayu, Masjid Kauman sebagai tetenger kawasan Kauman, dan Klenteng Tay Kak Sie sebagai tetenger Pecinan

\section{REKOMENDASI}

- Rekomendasi untuk Path / jalur di kempat kawasan kota lama Semarang, hanyalah sebaiknya diatur tentang akses satu jalur yang mengelilingi kawasan tersebut mengingat kepadatan aktifitas yang ada, serta pelebaran jalan dan pemisahan jalur pejalan kaki, dan juga tak lupa tempat parkir

- Edge atau batas wilayah sebaiknya diberi penanda khusus yang berkaitan dengan ke khasan wilayah tersebut pada batas luar, seperti yang sudah ada pada desain gerbang masuk kawasan Pecinan

- Rekomendasi district atau kawasan adalah penataan pemukiman pada Kampung Melayu dan penataan aktifitas perdagangan pada Kauman dan Pecinan sehingga dapat memperkuat image atau citra kawasan tersebut sesuai fungsinya

- Node atau simpul, titik kumpul, pembagi jalur seperti halnya rekomendasi edge, perlu diberikan ciri spesifik yang berbeda pada setiap node, sehingga masyarakat merasakan perbedaan yang signifikan dalam memasuki atau keluar dari setiap kawasan dari ke empat kawasan Kota Lama Semarang

- Rekomendasi landmark atau tetenger untuk Kota Lama Belanda, Kauman dan 
Pecinan tidak ada, hanya rekomendasi untuk tetenger Kampung Melayu yakni Masjid Layur yang perlu direvitalisasi baik fungsi religi dan budayanya maupun renovasi fisik tampilan lingkungan bangunan yang akan memperkuat landmark citra kawasan di daerah tersebut

\section{DAFTAR PUSTAKA}

Zahnd, Markus. 1999. Perancangan Kota secara Terpadu. Yogyakarta: Kanisius

Carr, Stephen, Mark Franchis, Leane G. Rivlin and Andrew M. Store (1992). Public Space, Press Syndicate of University of Cambridge, Australia.

Lynch, Kevin, ( 1962 ), The Image of The City, The H.I.T. Pressmassachusette.

Rapoport, Amos, ( 1975 ), Pengantar Sejarah Perencanaan Kota, Intermatra, Bandung.

Shirvani, Hamid. (1985). Urban Design Process. Van Nostrand Reinhold Company Inc: New York.

Trancik, R., ( 1986 ), Finding Lost Space : Theories of Urban Design, Van Nostrand Reinhold, New York.

Unterman, Ricard K, (1984), Accomodating the Pedestrian, Van Nostrand Reinhold Company, New York 